\title{
APPLICATIONS OF PHOTOMODELER IN PORT AU PRINCE, HAITI
}

\author{
Ridho Prawiro*, Regan Potangaroa**, Happy Ratna Santosa* \\ *) Department of Architecture, Institut Teknologi Sepuluh Nopember, \\ Indonesia \\ **) Department of Architecture, UNITEC, New Zealand \\ e-mail: perwiro@ymail.com
}

\begin{abstract}
Innovation and technology is increasingly considered the bedrock of an innovative and smart society and its consequent settlement. Habitat II, held in Istanbul, Turkey in 1996, endorsed important changes in the approach to human settlements, acknowledging the need for guiding urbanization, rather than preventing it. In all 171 governments adopted the agenda and the need to equitably spread the benefits of economic growth, and to fulfill basic housing and employment requirements. Translating these goals into quantitative, measurable targets has seemingly been problematic for engineers and architects and moreover, the application of technology as part of any innovative and smart settlement has been elusive. This paper looks at application of one innovative technology that has only developed recently using photographs to produce $3 D$ drawings of the photographed area. It looks at several areas of application in post disaster reconstruction in Port au Prince Haiti from the January 122010 earthquake. While the method is not especially site specific, its application in such a devastated context would suggest portability to other settlement disaster and non disaster in both. The key conclusion from this design based research is the need for quality as an integral part of any post disaster reconstruction program but also as part of any sustainable, innovative smart settlement.
\end{abstract}

Keywords: Habitat II agendas, quantitative, technology, photomodeler, Haiti

\begin{abstract}
ABSTRAK
Inovasi dan teknologi tumbuh berdasarkan pondasi inovasi, masyarakat yang cerdas dan kesadaran akan permukiman yang layak. Habitat II yang diadakan di Istanbul, turkey 1966, mengesahkan perubahan-perubahan penting dalam pendekatan permukiman, menyadari kebutuhan terhadap pedoman urbanisasi dari pada mencegahnya. Sekitar 171 pemerintah mengadopsi agenda tersebut karena kesadaran persamaan dan pemerataan di bidang ekonomi, pemenuhan perumahan dasar dan kebutuhan lapangan kerja. Menerjemahkan tujuan-tujuan tersebut menjadi
\end{abstract}


target-target yang dapat dihitung (kuantitatif) sepertinya telah menjadi masalah bagi para insinyur dan arsitek. Hal ini berakibat aplikasi teknologi sebagai bagian dari inovasi dan permukiman cerdas menjadi sulit dimengerti. Artikel ini memperlihatkan aplikasi dari sebuah teknologi inovatif yang dikembangkan baru-baru ini menggunakan fotografi untuk menghasilkan gambar $3 d$ dari bagian yang terpotret. Artikel ini mengaplikasikan penggunaan teknologi dalam rekonstruksi pasca bencana di Port Au Prince Haiti dari gempa bumi Januari 2010. Metode yang digunakan tidak spesifik di daerah tertentu dan dapat diaplikasikan pada konteks bangunan yang rusak terkena bencana maupun di permukiman yang tidak terkena bencana. Kesimpulan kunci penelitian ini adalah kebutuhan akan kualitas sebagai bagian yang terintegrasi dari setiap program rekonstruksi pasca bencana serta sebagai bagian dari setiap permukiman cerdas, inovatif dan berkelanjutan.

Kata kunci: agenda habitat II, quantitative, teknologi, photomodeler, Haiti

\section{INTRODUCTION}

Habitat II, held in Istanbul, Turkey in 1996, endorsed important changes in the approach to human settlements by acknowledging the need for guiding urbanization, rather than preventing it. In all 171 governments adopted the Agenda and the need to equitably spread the benefits of economic growth, and to fulfill basic housing and employment requirements. There was sense of hope for the future.

"This Conference in Istanbul marks a new era of cooperation, an era of a culture of solidarity. As we move into the twenty-first century, we offer a positive vision of sustainable human settlements, a sense of hope for our common future and an exhortation to join a truly worthwhile and engaging challenge, that of building together a world where everyone can live in a safe home with the promise of a decent life of dignity, good health, safety, happiness and hope" (General Assembly resolutions, 1996).

The details of the vision were stated in the 14 Agenda items but quantitatively translating these goals into measurable criteria has seemingly been problematic for engineers and architects preventing any application of technology. This has resulted in any innovative and smart settlement as being "elusive". This can be seen in the various attempts in the literatures review (Table 1).

For example, the first Agenda item of "Adequate Shelter and Sustainable Human Settlement" has 6 components but only "safer" appears to have any quantitative measures against which technology can be applied. Namely, in the form of codes, details, construction practices and materials. However, "healthier" while being able to show casual links does not go much beyond that and "more livable" does not appear to be linear in that doubling the floor area does not necessarily double adequacy or sustainability. "Equitable" remains seemingly relative while the inter- 
generational aspect of "sustainable" gives it an unoperational time frame. Finally "productive" usually through land use management seems to ignore where settlements are and that such changes are by their nature slow. This seems to be repeated through the other 13 items and hence the elusive characterization above. This could be why technology has not been readily applied to the Habitat II Agenda and suggests that the role of technology remains as a "loose" fit at best and not the "bedrock" mentioned earlier.

This paper looks at one certain technology in photogrammetry and provides 3 case studies and one verification study of how it can be used directly (and indirectly) to achieve an innovative smart settlement that supports local economy.

\section{Background}

Photogrammetry is the technology to convert a 2D photograph into a 3D image and has been defined by the International Society for Photogrammetry and Remote Sensing (ISPRS) as the "art, science, and technology of obtaining reliable information about physical objects and the environment through processes of recording, measuring and interpreting photographic images and patterns of recorded radiant electromagnetic energy and other phenomena" (ISPRS, 2012).

PhotoModeler Scanner is one software which uses the photogrammetry technology and was first released in October 1993 by Eos System Inc. It uses the calibration of the camera to determine position and includes tools to create accurate, high quality 3D models and measurements directly from photographs. The process is called photo-based 3d scanning. PhotoModeler Scanner is used in Accident Reconstruction \& Forensics, Archaeology, Architecture \& Preservation, Film \& Animation, Industry, Science \& Engineering, Geology / Mining \& Stockpiles and Biology / Medical (PhotoModeler, 2012).

Hence, the challenge posed by this paper is how could such technology (despite the elusiveness suggested by the Appendix 1 tabulation) nonetheless be used to address the Agenda items of Habitat II and contribute to "an innovative and smart settlement that enables local economy"?

\section{Literatures Review}

The literatures review of the Habitat II Agendas and the result of remained problematic in quantitative interpretations are presented in Table 1. 
Table 1. Literatures Review

\begin{tabular}{|c|c|c|c|}
\hline \multicolumn{2}{|c|}{$\begin{array}{l}\text { HABITAT II } \\
\text { Agenda } \\
\text { (General } \\
\text { Assembly } \\
\text { Resolutions, } \\
\text { 1996) }\end{array}$} & $\begin{array}{l}\text { Quantitative } \\
\text { Intrepretation }\end{array}$ & Implementation \\
\hline $\mathbf{1}$ & \multicolumn{3}{|c|}{ Adequate Shelter and Sustainable Human Settlement } \\
\hline & a. safer & $\begin{array}{l}\text { code } \\
\text { compliance }\end{array}$ & $\begin{array}{l}\text { Safer shelter should follow the rules in details, } \\
\text { constructions and materials (UN Habibat, 2009). }\end{array}$ \\
\hline & b. healthier & $\begin{array}{l}\text { improved } \\
\text { health } \\
\text { indicator }\end{array}$ & $\begin{array}{l}\text { In recent decades, two categories for building related to } \\
\text { health outcomes have been proposed on the basis of } \\
\text { strength and causality of the various observed health } \\
\text { effects: } \\
\text { - Building Related Illness (BRI) } \\
\text { - Sick Building Syndrome (SBS). } \\
\text { Still, these two categories are insufficient to cover the } \\
\text { relationship between housing and health (Bonnefoy, X. } \\
\text { (2007). }\end{array}$ \\
\hline & $\begin{array}{l}\text { c. more } \\
\text { livable }\end{array}$ & $\begin{array}{l}\text { usually floor } \\
\text { area }\end{array}$ & $\begin{array}{l}\text { The technical evaluation of the regional growth strategy } \\
\text { in livable human settlement with criteria of: region } \\
\text { character, community's identity are measured by the } \\
\text { amount of compactness with number of hectares of land } \\
\text { in centres. This means that higher is better (Technical } \\
\text { Evaluation Regional Growth Strategy, 2000). }\end{array}$ \\
\hline & d. equitable & $\begin{array}{l}\text { remained } \\
\text { problematic }\end{array}$ & $\begin{array}{l}\text { The social security of urban-rural is and important part of } \\
\text { development in human settlement, therefore it is } \\
\text { suggested that people are first priority of the development } \\
\text { and improvement of their livelihood (Zengcheng } \\
\text { Municipal Government, 2010). }\end{array}$ \\
\hline & $\begin{array}{l}\text { e. sustain- } \\
\text { able }\end{array}$ & $\begin{array}{l}\text { intergeneratio } \\
\text { nal test }\end{array}$ & $\begin{array}{l}\text { The sustainability's second dimension suggests the degree } \\
\text { of which the settlement reflects, in structure, form and } \\
\text { even the timeless qualities. The sustainable settlements } \\
\text { accommodate well growth and change in structural order } \\
\text { in which allows the logical reinterpretation of the } \\
\text { successive generations to have a strongly spatial feel with } \\
\text { definition of generously public spaces which are not } \\
\text { determined only by immediate needs but by recognition } \\
\text { that public space is important in its own right (CSIR } \\
\text { Building and Construction Technology,2005 p.5 chapter } \\
\text { 2). }\end{array}$ \\
\hline & $\begin{array}{l}\text { f. produc- } \\
\text { tive }\end{array}$ & $\begin{array}{l}\text { economic } \\
\text { indicator }\end{array}$ & $\begin{array}{l}\text { The supplementary of new subregional treaties of } \\
\text { economic development should achive balanced } \\
\text { development of the region through efficient land use }\end{array}$ \\
\hline
\end{tabular}


management to develop in competitive city systems which is supposed to provide scope for economic progress in region, while making sure the appropriate living conditions in environmental sustainability (Cepal, 2001).

\begin{tabular}{|c|c|c|}
\hline 2 & Cities and & own \\
\hline & $\begin{array}{l}\text { a. social } \\
\text { advan- } \\
\text { cement }\end{array}$ & $\begin{array}{l}\text { remained } \\
\text { problematic }\end{array}$ \\
\hline & $\begin{array}{l}\text { b. cultural } \\
\text { advan- } \\
\text { cement }\end{array}$ & $\begin{array}{l}\text { remained } \\
\text { problematic }\end{array}$ \\
\hline & $\begin{array}{l}\text { c. spiritual } \\
\text { advan- } \\
\text { cement }\end{array}$ & $\begin{array}{l}\text { remained } \\
\text { problematic }\end{array}$ \\
\hline
\end{tabular}

d. scientific remained advan- problematic Sustainable Cities are Fundamental to Social and Economic Development, cities are important centres of productivity and social advancement (UNCHS and UNEP, 2012)

A group of cities, including London, Barcelona, Paris, and Nuremberg represent lead cities that are following the Ten-Point Plan of Action.

These world cities are places and supposed to be the space where good practice of anti-racism for social cohesion, insclusive citizenship, prosperity in economic and cultural advancement can be shared by other cities around the world (UNESCO, 2006).

There is a Japanese NGO called by Organization for Industrial, Spiritual and Cultural Advancement (OISCA) registered in UN database 9 (JICA, 2008).

cement

WRIA 9 Habitat Plan actions is implemented to enhance and increase the ecosystem value within watershed, namely: flood protection, maintenance of natural storm water, water drinking and filtration production, the reduction of pathogens and pollutants, absorption of waste, storm protection, preservation of biodiversity, regulation on nutrient, more production of fish, shellfish and other food and raw materials. Control of erosion, biodiversity, aesthetic value, recreational fishing, hiking, hunting, bird watching, educational and scientific benefits (Asia Pacific Environmental Exchange, 2005).

\begin{tabular}{llll}
\hline 3 & $\begin{array}{l}\text { Better } \\
\text { standards } \\
\text { of living }\end{array}$ & $\begin{array}{l}\text { economic } \\
\text { indicator such }\end{array}$ & $\begin{array}{l}\text { Countries with big population like India use GDP as main } \\
\text { indicator for better standart living (McKinsey Global }\end{array}$ \\
& as GD & Institute, 2010).
\end{tabular}

4 Improving quality of life within human settlements by combatting:

a. lack of selected UN-Habitat Responses:

basic infra indicator - Water and Sanitation Trust Fund Strategic Plan (2008structure 2012)

and

- Delivering sustainable services for the poor

services

- Ensuring synergies between the built and natural environment

- Monitoring the Millennium Development Goals and beyond 
b. lack of adequate planning
- Integrating infrastructure and housing (UN-HABITAT, 2009)

precision of urban plan

The Provincial Department has successfully identified the slum clearance project as top priority, but unfortunately the programs are affected by number of issue include a lack of adequate planning by most municipalities at both IDP and sector planning level (UN-HABITAT, 2007).

\section{Cities must be places where human beings lead fullfilling lives in:}

a. good remained The plan mentions the idea of sanitation importance in the health problematic city for good health to establish the need of solid waste management system in the city, especially in the slum area (School of Planning and Architecture, 2012).

$6 \quad$ Rural and urban development

a. extend remained "Minimally the applicant of approval development will be adequate problematic infra required to construct or extend aroad network that will:

structure

- Provide a safe, efficient and convenient traffic circulation pattern.

$\begin{array}{ll}\text { b. public } & \text { remained } \\ \text { services } & \text { problematic }\end{array}$

- Provide adequate access to all adjacent properties and eliminate the potential for landlocked parcels.

c. develop remained integrated problematic network of

- Extend adequate infrastructure to provide municipal services.

- Create a circulation system that will provide adequate public safety and emergency access to protect both human life and the built environment" (p.19-17)

settlements

"In order to promote a public service or event, or to provide public information, the City may place signage on City owned property, following approval by the City Council. Public purpose signs may include the following:

- Wall signs attached to a publicly owned building or structure.

- A monument sign that does not exceed sixty four (64) square feet and is no more than six (6) feet in height.

- Directional signs necessary to direct vehicular and pedestrian traffic.

- Reader board and message centers provided that the sign will not impact residential uses" (p.19-189). (Payson City Zoning Ordinance, 2012)

\section{Basis in implementing Habitat agenda:}

a. safe, remained healthy and problematic secure living condition (for women,
The emergency/minor repair program is intended to provide assistance for eligible home owners to have safe, sanitary and secure living condition, they are not limited to repair, replacement or modification of:

Roof

Plumbing

Sewer
Hot Water Heater

Furnace/Heating System

Electrical 

childer and
youth)
b. provide
remained
basic needs problematic

Floor (structural)
City Code Violation

Weatherization

The main focus in on accessibility Improvements for homes where have the disabled individuals Resident (Home Helpers of North Idaho, 2012)

\section{Sustainable global environment and improve quality of life:}

a. sustaina- remained ble patterns problematic of settlements development

b. respect for the carrying capacity of ecosystems

remained problematic
"Programmes have been implemented in many countries in the region, including Argentina, Bolivia, Brazil, Chile, Colombia, Costa Rica, Ecuador, El Salvador, Guatemala, Honduras, Peru and uruguay. They are in situ urbanization programmes that take advantage of the investments the residents have already made in their housing solutions, and emphasize community participation in the execution of operations" (p.16)

"A third area relates to the integration of urban environmental management practices into land use planning instruments (Cordoba, Argentina; Manizales and Bogota in Colombia; and Santiago, Chile). In Santiago, with the collaboration of the German Technological Cooperation Agency (GTZ), the regional government launched the Environmentally Sustainable Land Use Planning Project (OTAS), to support the regional government in land use planning and decision making in four key areas (human settlements systems, transportation, socio-production systems, and physical environmental systems). Based on a methodology called landscape planning, developed in Germany for the protection of nature and landscape, this project has created an ecological inventory of the Metropolitan Region of Santiago, elaborated environmental maps and environmental based criteria for land use" (p.19)

(Winchester, L., 2005)

11 For monuments, open spaces, landscapes and settlement patterns of historical, cultural, architectural, natural, religious and spiritual value:

$\begin{array}{ll}\begin{array}{l}\text { a. conserva- } \\ \text { tion }\end{array} & \begin{array}{l}\text { remained } \\ \text { problematic }\end{array} \\ \begin{array}{l}\text { b. rehabili- } \\ \text { tation }\end{array} & \begin{array}{l}\text { remained } \\ \text { problematic }\end{array} \\ \begin{array}{ll}\text { c. mainte- } \\ \text { nance }\end{array} & \begin{array}{l}\text { remained } \\ \text { problematic }\end{array}\end{array}$

Heritage conservation has many potential for cultutal, social, economic and environmental benefits. Heritage conservation allows a community to retain and convey the sense of its history while provides the aesthetic enrichment as well as educational opportunities. The heritage resources are helpful for understanding the source of where we have come from to appreciate what we can do next for continuity of our built environment from past to present and to future.

Historical buildings and landscapes become landmarks and touchstone of the community which serve them to the 
moderate impact of the rapid change in the environment. The historical buildings in Strathcona County tell us that:

- Heritage conservation allows a community to retain and convey a sense of its unique history.

- A coordinated approach to heritage planning can take advantage of partnership opportunities with senior levels of government, and engage the private and volunteer sectors.

- Heritage initiatives have a strong positive impact on developing socially-sustainable communities and creating a vibrant culture of creativity and innovation.

- The preservation of historical sites supports tourism development and education.

Most of historical conservations are often linked to the tourism initiatives. Many regional examples show the success of this approach, even there is a growing research evidence that cultural and heritage based tourism is now becoming the fastest growing segment of the growing tourism industry.

The other benefits of strong heritage policies include creating distinctive neighbourhoods, preserving cultural heritage, providing community identity and pride and even combating social issues by engaging youth in the history and identity of their community.

The restoration and preservation of heritage buildings can be marketed as a tool to create positive economic development and cultural sustainability (Luxton, Donald \& Associates incc., 2008) 


\section{RESULTS AND DISCUSSION}

\section{Case Studies in Port Au Prince, Haiti}

Three case studies and one verification study were undertaken as part of a post disaster reconstruction programme in Port au Prince, Haiti. The post disaster context of these studies is perhaps not so relevant as opposed to their ability to provide a platform for innovative, smart settlements that can be used to impact on the local economy. This seems to follow the holistic nature of such complex systems in that no one technology could be expected to directly or immediately impact fully in this way.

PhotoModeler Scanner requires only 1 photograph but further ones will increase the positional accuracy. In practice a minimum of 3-4 photographs were found to be necessary to produce a usable 3D perspective. Further images depending on the situation would benefit with additional photographs. For example, a narrow linear ravine seemed to require more photographs than a wide plaza area. Thus, the first study was to check the accuracy of the process against direct measurement. We took 4 overlapped photographs of a container building, modelled it and checked its actual dimensions against what PhotoModeler calculated.

Input photographs:
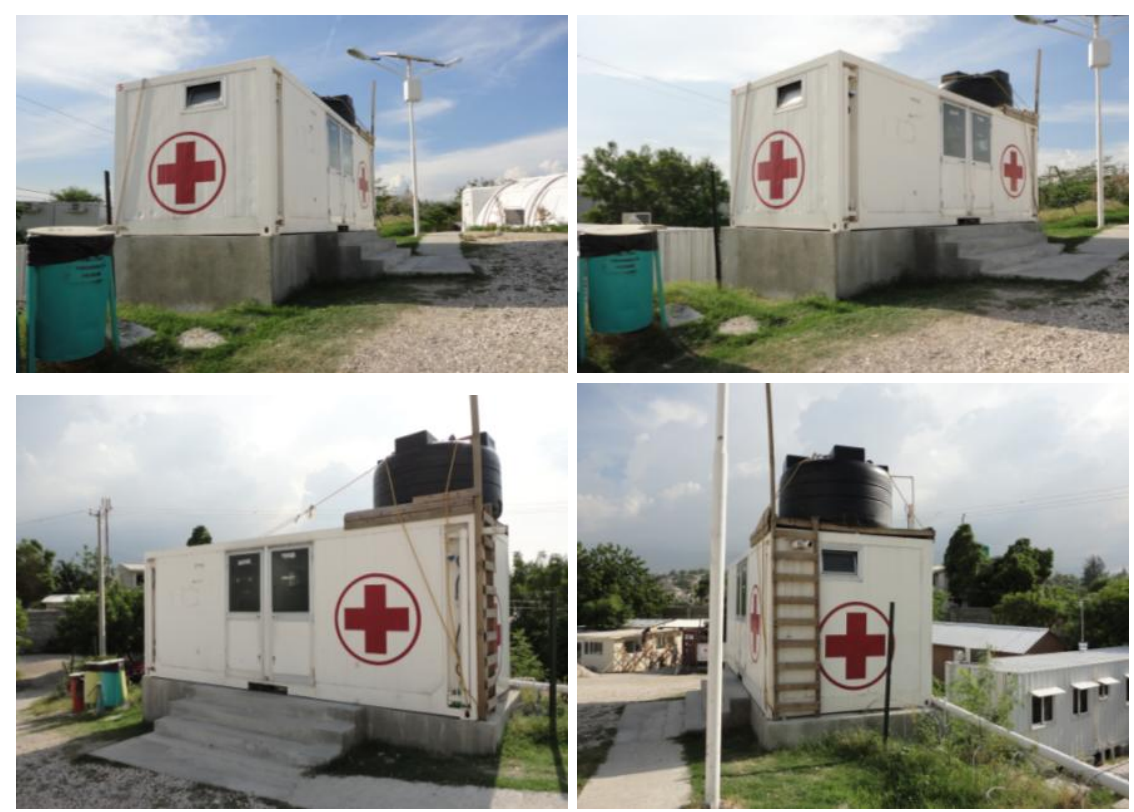

Figure 1. Input Photographs for Container

Source: author's documentation 
3D result:

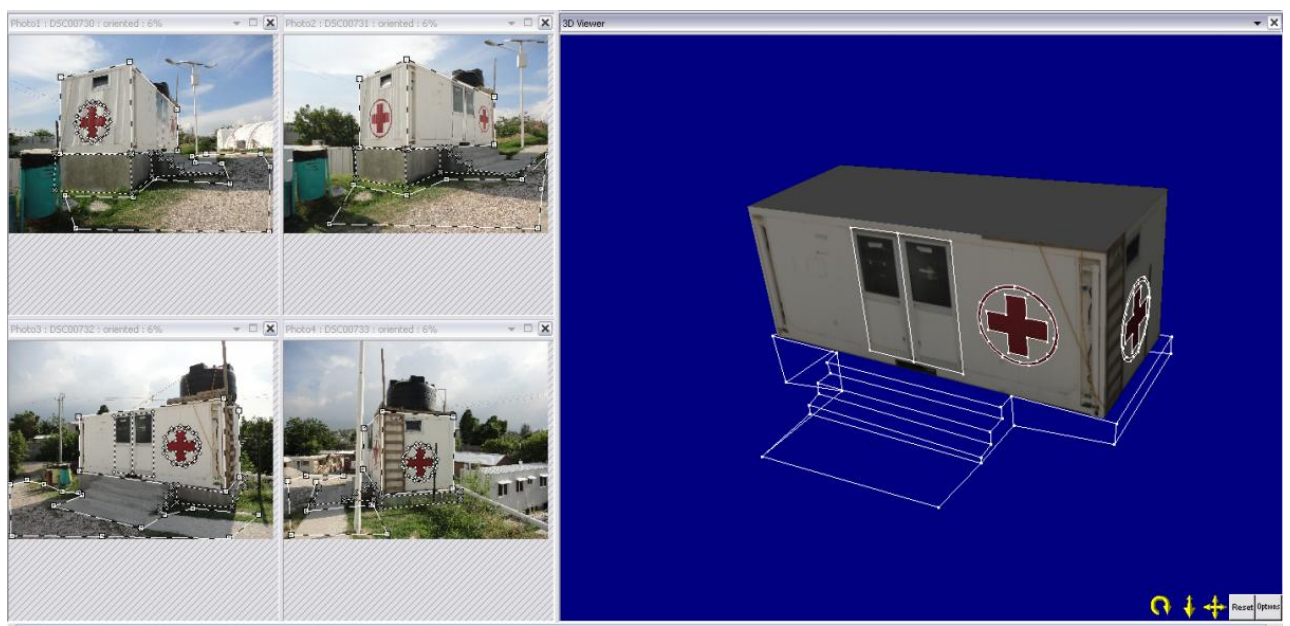

Figure 2. 3D Result for Container

Source: author's documentation

Accuracy:

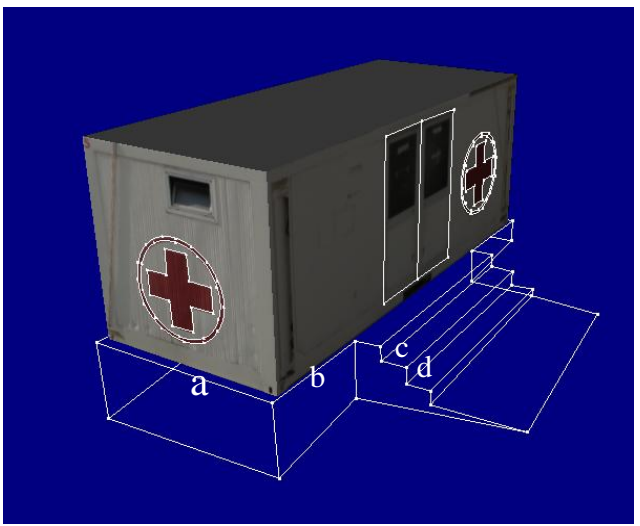

1 line[s][Lines:70]

Length: $2590.000 \mathrm{~mm}$

Distance in $X, Y Z: \quad 2589.603, \quad 40.040, \quad-21.259 \mathrm{~mm}$ ...

1 line[s][Lines: 67$]$

Length: $1596.203 \mathrm{~mm}$

Distance in $X, Y Z: \quad 22.775,1596.006, \quad 10.497 \mathrm{~mm}$ $\cdots$

1 line[s][Lines: 45$]$

Length: $323.695 \mathrm{~mm}$

Distance in $X, Y Z: \quad 320.352, \quad 46.400, \quad-0.451 \mathrm{~mm}$

1 line[s][Lines:46]

Length: $215.870 \mathrm{~mm}$

Distance in $X, Y Z: \quad 6.816, \quad 28.144,-213.919 \mathrm{~mm}$

Figure 3. Accuracy for Container

Source: author's documentation

Table 2. Accuracy Study

\begin{tabular}{llll}
\hline Line & In reality $(\mathbf{m m})$ & $\begin{array}{l}\text { In PhotoModeler Scanner } \\
(\mathbf{m m})\end{array}$ & $\begin{array}{l}\text { Accuracy Different } \\
(\mathbf{m m})\end{array}$ \\
\hline $\mathrm{a}$ & 2590 & 2590.0 & As reference \\
$\mathrm{b}$ & 1590 & 1596.2 & +6.2 \\
$\mathrm{c}$ & 330 & 323.6 & -6.4 \\
$\mathrm{~d}$ & 210 & 215.8 & +5.8 \\
\hline
\end{tabular}

Note: The $3 \mathrm{D}$ accuracy is as shown in the table. 
From table 1 above it can be seen that the accuracy varied from $-6.4 \mathrm{~mm}$ to +6.2 $\mathrm{mm}$. Nonetheless, this was well within acceptable construction tolerances at least for the larger dimensions and a variation of $5.8 \mathrm{~mm}$ on $210 \mathrm{~mm}$ though larger in terms of percentages was still workable. On the other hand one did need to be aware of any cumulative errors generated by partial measurements rather than overall ones. It was nonetheless, encouraging as it seemed to suggest that we could firstly efficiently and effectively measure and secondly that these measurements would be sufficiently "accurate". This seemed to offer other indirect benefits to the communities in Port au Prince.

The ongoing studies and then seem to be divided into three different main topics:

1. Damaged condition building

PhotoModeler scanner is good in creating 3D of damaged building which is very important for disaster area like in Haiti. This has advantages of ease of access for site inspection say of houses to be retrofitted or construction of a new building as in this particular case. Here two of one which had partially collapsed. 15 photographs were used to produce the $3 \mathrm{D}$ perspective.

Input photographs:
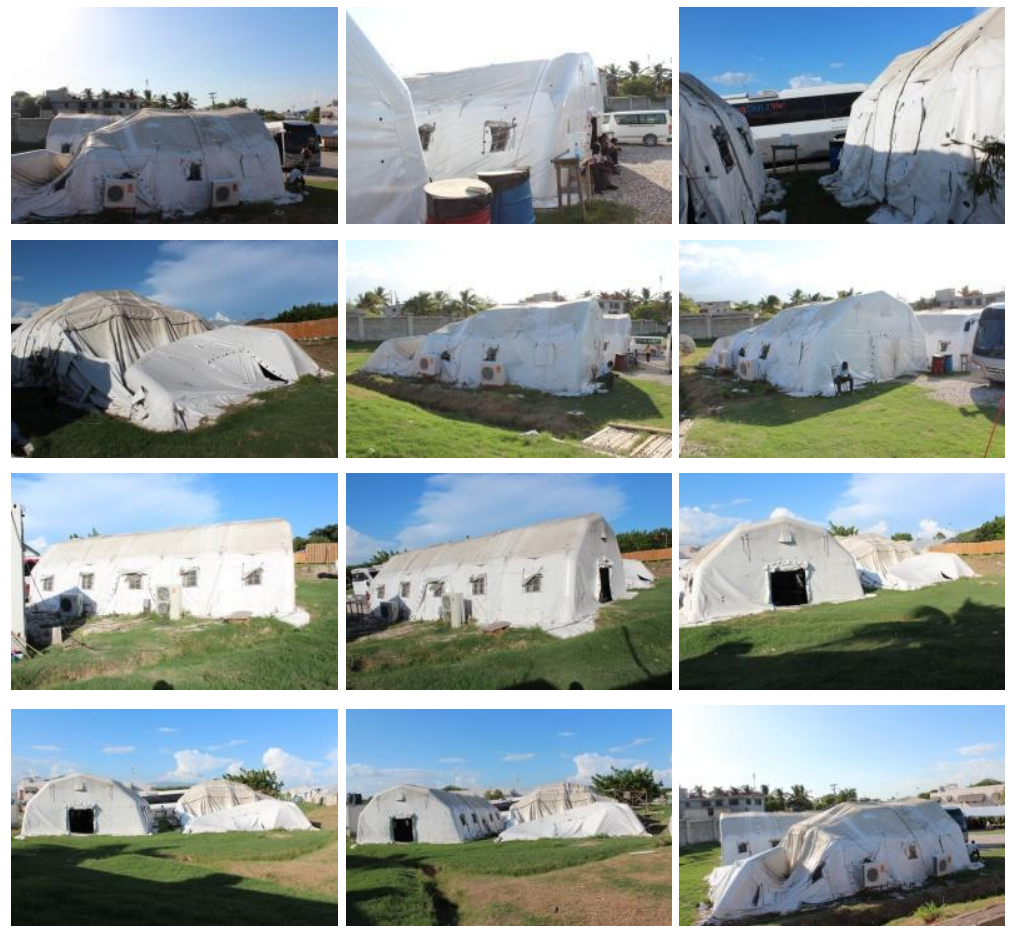

Figure 4. Input Photographs for Broken Tents

Source: author's documentation 
3D result:

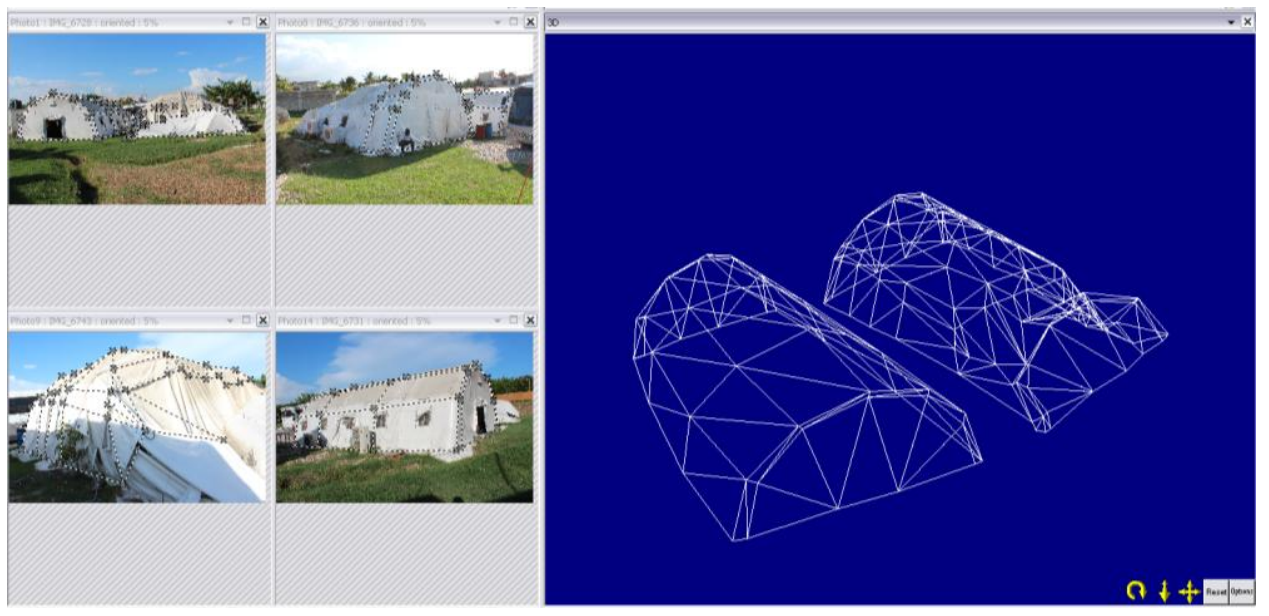

Figure 5. 3D Result for Broken Tents

Source: author's documentation

Damage study:
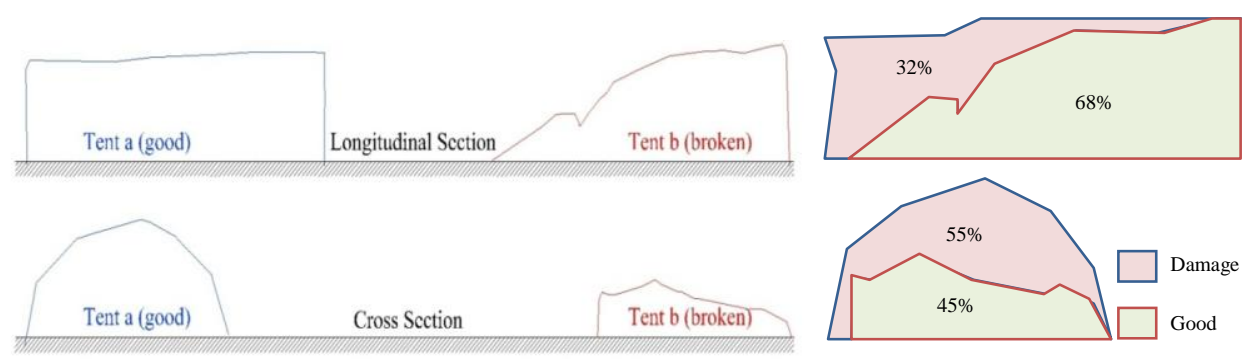

Figure 6. Damage Study for Broken Tents through Sections

Source: author's documentation and analysis
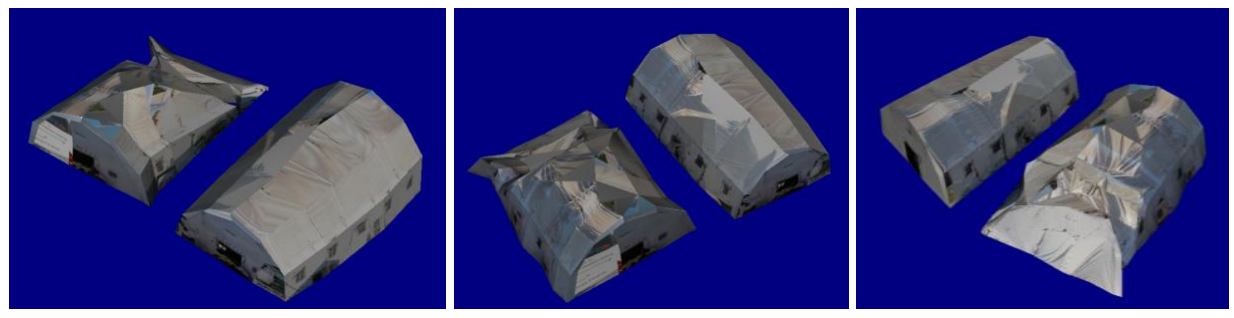

Figure 7. 3D Result of Damage Study in Rendering Image Source: author's documentation and analysis

Note that from these figures we can learn the damage composition of the building. We also can measure the size of the damage to calculate the estimation 
on retrofitting process as shown in Figure 6 for damage ratio. In a similar way it reduced dependency on "sorting it out on site".

2. Wide area construction (for monitoring ongoing project)

PhotoModeler Scanner can be used for wide area construction, the only problem that it would need more photographs to be taken from the site to construct a 3D of an area. For the sample, we used British Red Cross (BRC) pavement and canal area in Delmas 19. It generated work that could be done by the Community Based Organisations (CBO) to help understanding whether their work has a good quality in term of accuracy and sense of space. For example paving steps and alleyways and ravine work, these in turn opened up other possibilities such as always along the ravine work, better and easier access for transporting water (usually carried in from nearby water kiosks).

Input photographs:
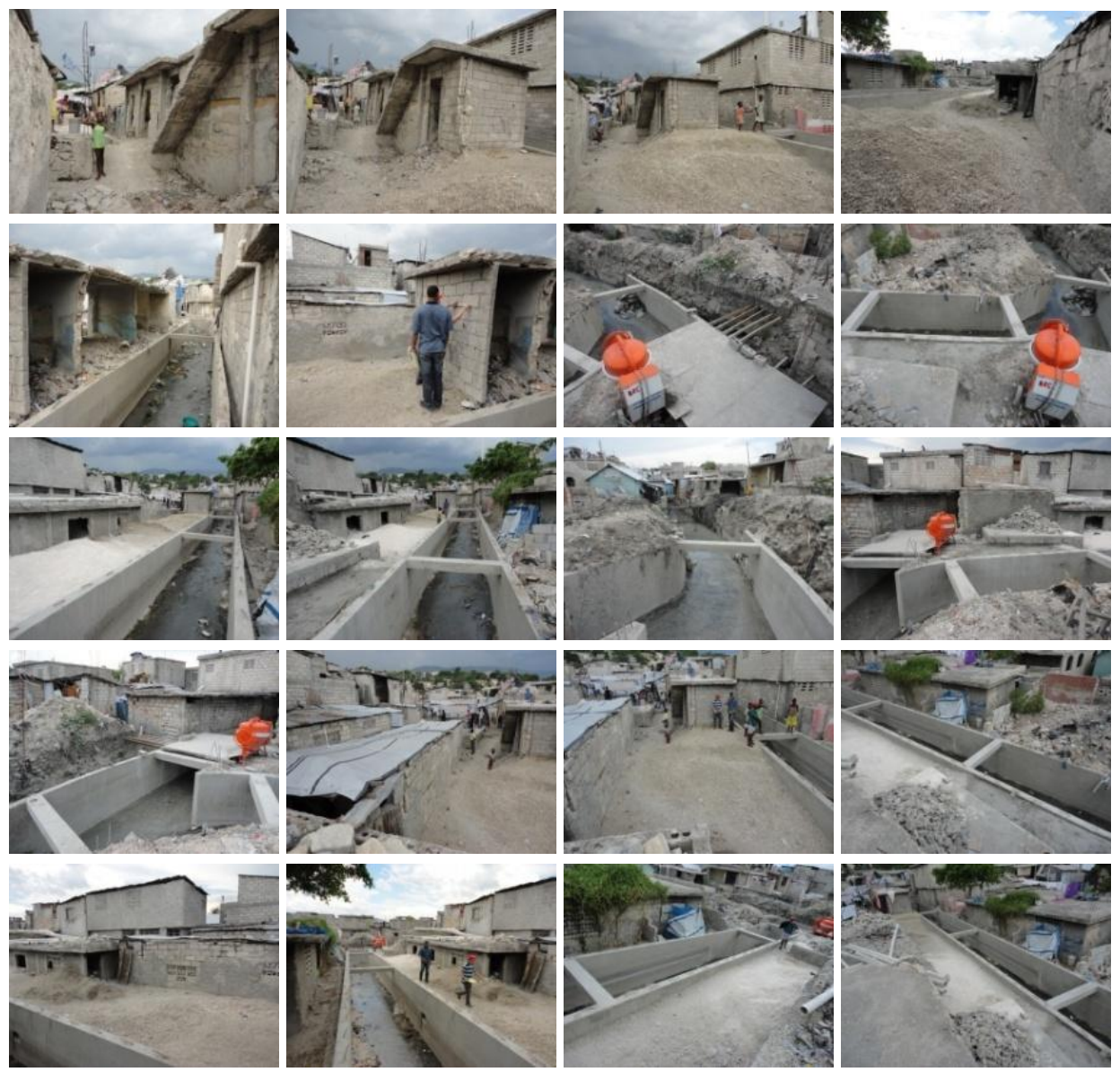

Figure 8. Input Photographs for CBO's Project in Delmas 19, PAP-Haiti Source: author's documentation 
3D result:

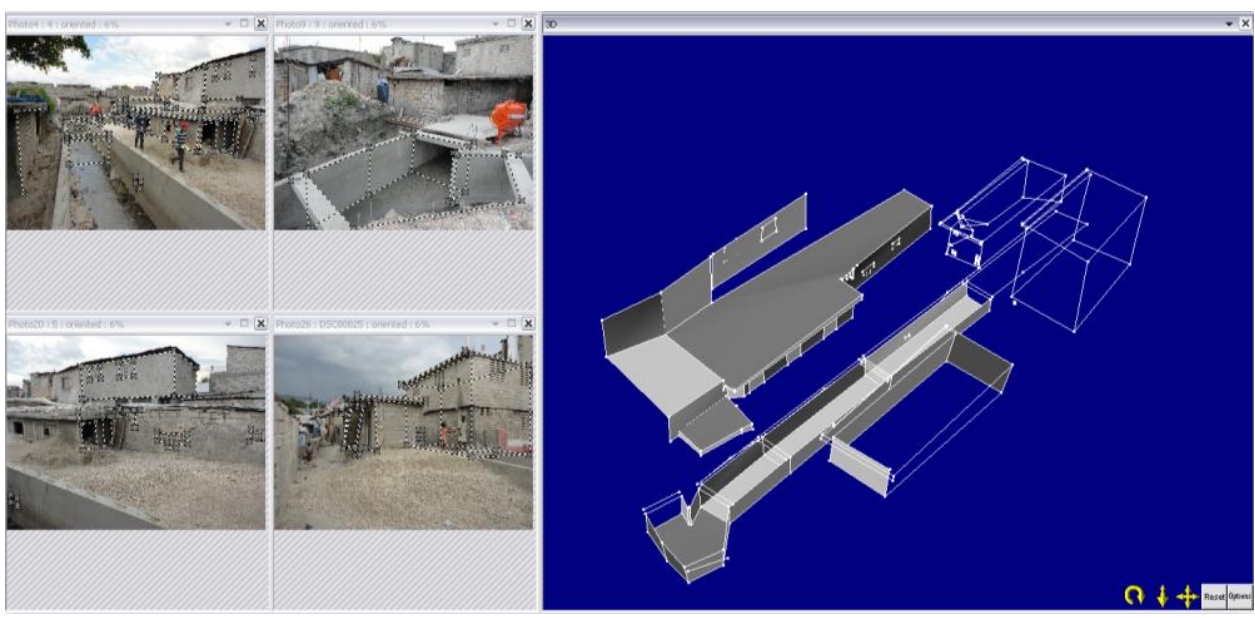

Figure 9. 3D Result for CBO's Project in Delmas 19, PAP-Haiti Source: author's documentation

Comparison study:
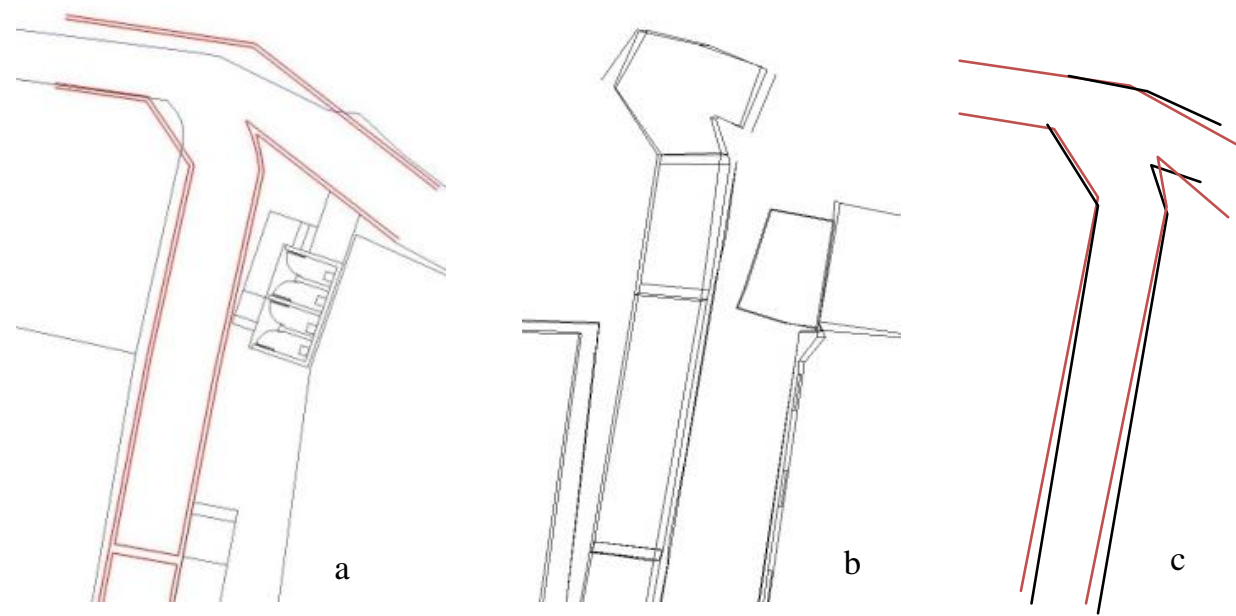

Figure 10. Monitoring Study for CBO's Project in Delmas 19, PAP-Haiti From Left to right: a) Design Plan, b) Plan from PhotoModeler Scanner, c) Comparison Study Source: author's analysis

Note that from the sample we can measure the accuracy of the ongoing project by comparing the design on paper with the design realization in the site.

3. Terrain

Creating terrain is what PhotoModeler Scanner can do that PhotoModeler cannot do, so basically the scanner can do better in 3D modelling because it can use 
point cloud from the object and create 3D based on the points. For this case, we want to create a 3D of one part of Ravine Salem by generating 5 photographs from the site. For bigger area would need more photographs.

Input photographs:

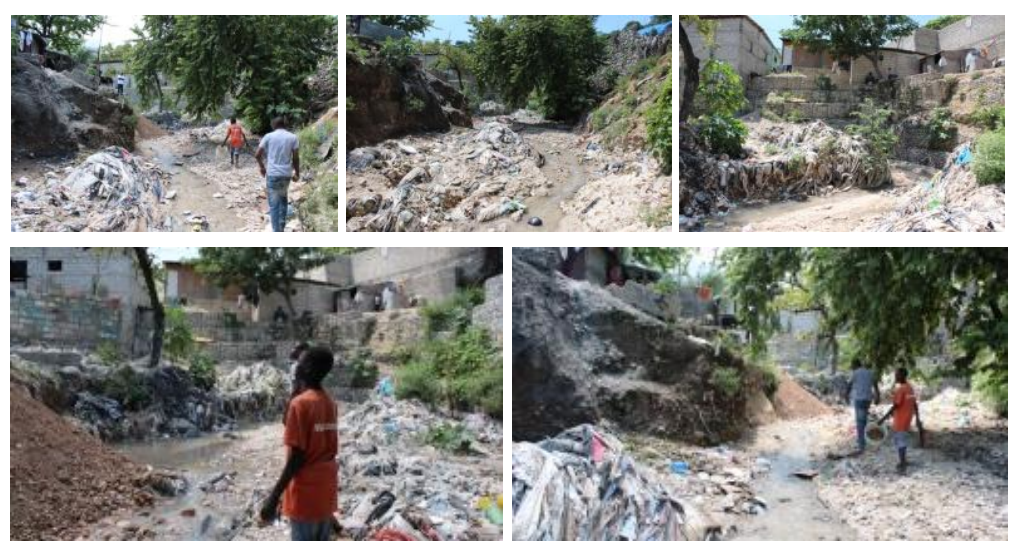

Figure 11. Input Photograph in Ravine Salem Project Source: author's documentation

3D result:
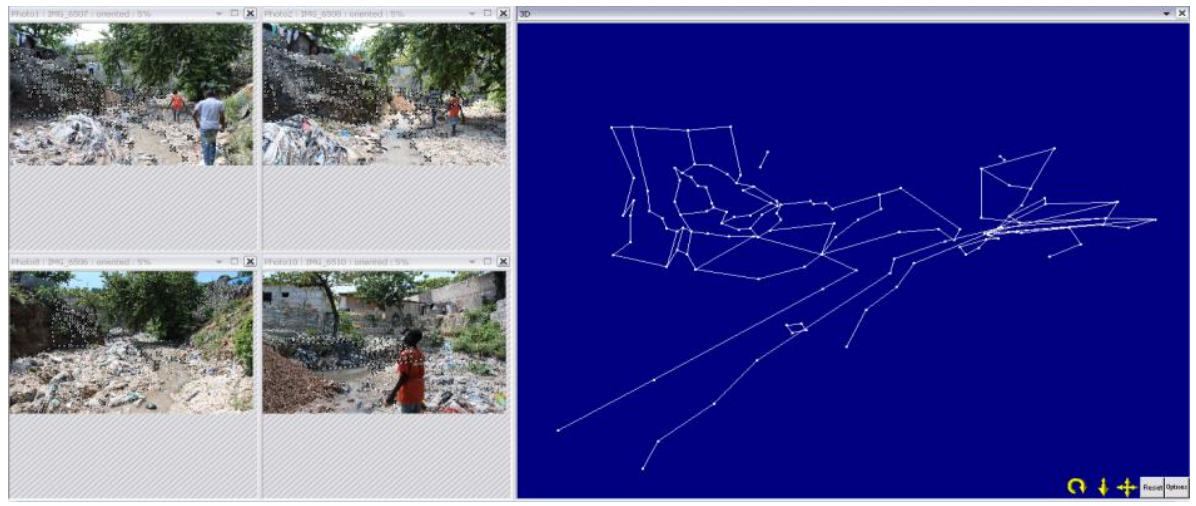

Figure 12. 3D Result of Creating Terrain in Ravine Salem Project Source: author's documentation
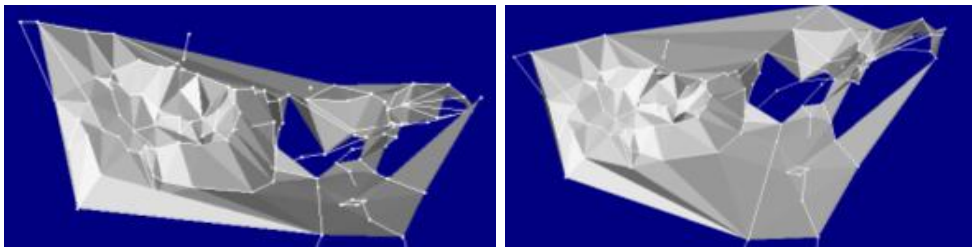

Figure 13. 3D Result of Creating Terrain in Shaded View Source: author's documentation 
Note that its accuracy allowed work off to be completed off site and more efficient construction with reduced waste of material and effort. This is very useful for humanitarian projects especially for WATSAN (Water and Sanitation) and another projects work with more terrains like in Haiti.

\section{CONCLUSIONS}

The case studies suggest the following about the role and use of technology:

1. Meant that we could efficiently and effectively accurately measure something that would have otherwise been difficult or not possible at the accuracy suggested by the container study. That meant we could do better design work, set out for construction and hence any associated planning. For example, it opened up opportunities for coloured precast pavers which were both innovation as well as addressing issues of Habitat II.

2. In a similar way it reduced dependency on "sorting it out on site".

3. It generated work that could be done by the Community Based Organisations (CBO). For example paving steps and alleyways and ravine work. These in turn opened up other possibilities such as always along the ravine work, better and easier access for transporting water (usually carried in from nearby water kiosks).

4. Its accuracy allowed work off to be completed off site and more efficient construction with reduced waste of material and effort. For example in the ravine study.

Finally, the sense gained from this work (and it is one that will be researched further) was the need but maybe the desire for "Quality". In many situations and perhaps especially post disaster reconstruction the need seems to be to provide a seemingly "soulless" minimum. The experience of the team doing this work was that technologies such as these somehow raised the issue of Quality and the construction detailing perhaps because of its accuracy were being re-evaluated in the light of accurate ground data. This was unexpected but refreshing and perhaps support what Alexander called "The Timeless Quality” (Alexander C., 1979).

\section{REFERENCES}

Alexander, C. (1979), The Timeless Way of Building, Oxford Press

Asia Pacific Environmental Exchange (2005), Ecosystem Services Enhanced by Salmon Habitat Conservation in the Green/Duwamish and Central Puget Sound Watershed, <http://www.eartheconomics.org/FileLibrary/file/Reports /WRIA_9_Ecosystem_Service_Analysis.pdf > (Accessed on 22 November 2012).

Bonnefoy, X. (2007), Inadequate Housing and Health: An Overview, Int. J. Environ ment and Pollution, Vol. 30, Nos. 3/4, 2007. 
Cepal (2001), Latin American and Caribbean Regional Plan of Action on Human Settlements UPDATED VERSION, Santiago, Chile, p.12, <http://www. cepal.org/pobrezaurbana/docs/minurvi/IXForo/PlanofactiononHumanSettle ments.pdf $>$ (Accessed on 22 November 2012).

CSIR Building and Construction Technology (2005), Guide lines for Human Settlement Planning And Design Volume 1, <http://www.dhs.gov.za/Content /Publications/Volume_I_new.pdf> (Accessed on 22 November 2012).

General Assembly Resolutions (1996), Istanbul Declaration on Human Settlements, <http://www.unhabitat.org/downloads/docs/407-ISTANBUL_DECLARAT ION_ON_HUMAN_SETTLEMENTS-Istanbul_Declaration.pdf $>$ (Accessed on 9 October 2012).

Home Helpers of North Idaho (2012), North Idaho Senior ReSources, p. 109, $<$ http://coeurdalenehomecare.com/Library/website-images/ReSource_Book _pdf.pdf> (Accessed on 23 November 2012).

International Society for Photogrammetry and Remote Sensing (ISPRS) (2012), International Society for Photogrammetry and Remote Sensing, <http:// www.isprs.org/> (Accessed on 29 October 2012).

JICA (2008), Understanding Japanese NGOs from Facts and Practices, <http:// www.jica.go.jp/english/publications/jica_archive/brochures/2008/pdf/ngo_d is.pdf $>$ (Accessed on 22 November 2012).

Luxton, Donald \& Associates inc. (2008), Strathcona County Heritage ReSource Management Plan, p.6, <http://www.strathcona.ca/files/Files/at-COMMAB-STR-HRMP-FINAL-Report-6-15-09.pdf> (Accessed on 23 November 2012).

McKinsey Global Institute (2010), India's Urban Awakening: Building Inclusive Cities, Sustaining Economic Growth, <http://www.mckinsey.com/ /media /McKinsey/dotcom/Insights\%20and\%20pubs/MGI/Research/Urbanization/I ndias\%20urban\%20awakening\%20Building\%20inclusive\%20cities/MGI_In dias_urban_awakening_full_report.ashx>(Accessed on 22 November 2012).

Payson City Zoning Ordinance (2012), Title 19 Zoning Ordinance, p. 19-17 and p.19-189, <http://www.paysonutah.org/img/File/CityCode/Title\%2019\%20 Zoning\%20Adopted\%205-16-12.pdf > (Accessed on 23 November 2012).

PhotoModeler (2012), Measuring and Modeling the Real World, <http://www.photo modeler.com/> (Accessed on 29 october 2012).

School of Planning and Architecture (2012), Alternative Approches to Development Plant, p.6-17, <http://www.spa.ac.in/Alternative-to-Master-Plan-Apporach. pdf $>$ (Accessed on 23 November 2012).

Technical Evaluation Regional Growth Strategy (2000), Livable Human Settlement, <http://www.crd.bc.ca/regionalplanning/growth/documents/TechnicalEvalu ationofRGSLivableHumanSettlementDescriptor.pdf> (Accessed on $22 \mathrm{Nov}$ ember 2012).

UNCHS and UNEP (2012), Sustainable Cities and Local Governance, The Sustain able Cities Programme (SCP), p.3, <http://www.unhabitat.org/pmss/get Elec tronicVersion.aspx?nr=1866\&alt=1> (Accessed on 22 November 2012). 
UNESCO (2006), International Public Debates: Urban Policies and Right to the City, <http://unesdoc.unesco.org/images/0014/001461/146179m.pdf> (Acc essed on 22 November 2012).

UN-HABITAT (2007), Situation Analysis Of Informal Settlements In South Africa: City Of Urban (Ethekwini) Umlazi \& Kenville/Sea-Cow Lake, Cities With out SLums, Sub-Regional Programme for Eastern and Southern Africa, $<$ http://www.unhabitat.org/pmss/getElectronicVersion.aspx?nr=1866\&alt=1 $>$ (Accessed on 22 November 2012).

UN-HABITAT (2009a), How to Build a Safer Shelter (a guide to households on how to build that is safer against natural forces), <http://www.unicef. org/education /files/UNHabitat_Shelter_Jun2009.pdf> (Accessed on 15 Nov ember 2012).

UN-HABITAT (2009b), Basic infrastructure services, International tripartite confe rence on urbanization challenges and poverty reduction in African, Carib bean and Pacific countries, First meeting Nairobi, 8-10 June 2009, <http:// www.unhabitat.org/downloads/docs/6816_51547_K0951983\%20HSP-EC-

ACP-1-7\%20Basic\%20infrastructure\%20services.pdf> (Accessed on 22 No vember 2012).

Winchester, L. (2005), Sustainable human settlements development in Latin America and the Caribbean, Santiago Chille, <http://www.eclac.cl/publicaciones/xml 13/21543/lcl2287i.pdf> (Accessed on 23 November 2012).

Zengcheng Municipal Government (2010), Developing A Livable City-AModel for Sustainable Development, Application for UN-HABITAT Scroll of Honour 2010, China, p.10, <http://www.urbangateway.org/sites/default/ugfiles/Zeng cheng\%20City.pdf> (Accessed on 22 November 2012). 